\title{
THE VALUE OF THE DISTINCTION BETWEEN DIRECT AND COLLATERAL ATTACKS ON JUDGMENTS
}

\author{
"Is this a direct or collateral attack on the judgment ... ? The answer \\ to that query in judicial pronouncements ... has led through a maze of \\ verbiage and resulted in no little confusion." Farley, J., in Bates v. Mitchell, \\ 67 Ariz. 151, 154, 192 P.2d 720, 722 (1948).
}

THE distinction between a "direct" and "collateral" attack on a final judgment is one of the most obscure areas of procedural law. ${ }^{1}$ Yet there is a vast difference in result between the two; a party's success in avoiding the effect of an allegedly defective prior judgment depends largely upon whether the court classifies the attempt direct or collateral. ${ }^{2}$ In deciding which of the two labels to attach in a given situation, courts have disagreed as to the controlling factors, and have frequently resorted to purely formal distinctions unrelated to a meaningful policy rationale. ${ }^{3}$ In view of the recurring nature of the problem ${ }^{4}$ and the present uncertainty of the law, an analysis is warranted of the consequences following the classification of the attack, the determinative criteria and the justification for the basic dichotomy.

\section{The Permissible Scope of Attack in Direct and Collateral Proceedings}

The irregularities which may occur in the course of a proceeding terminating in a judgment are divided by the law into two broad categories. Nonjurisdictional defects such as mistake of law by the trial court, procedural irregularities, or fraud, excusable neglect and other circumstances warranting relief may render a judgment voidable, but not void. ${ }^{5}$ Such defects cannot be challenged by a so-called collateral attack and may be reached only by some form of direct attack. ${ }^{6}$ In contrast, a court's failure to obtain jurisdiction over

1. "Except in the light of some ... particular purpose, attempted distinctions are probably futile." ARnold \& James, Cases oN Trials, Judgments and Appeals 137 (1936).

2. See text at notes 6-9 infra.

3. See text at notes 55-57 infra.

4. During the period $1946-56$ the outcome of over 120 reported cases was dependent upon whether an attack was held direct or collateral. In countless other cases the determination of this question was essential to the decision but not specifically in issue. See West's Dec. Dig., Judgments key number 518 (1946-56).

5. See, e.g., Ex parte Tyler, 152 Tex. 602, 261 S.W.2d 833 (1953) (error of law); Batey v. Batey, 35 Wash. 2d 79, 215 P.2d 694 (1950) (fraud) ; 1 Freeman, JudgMents $\$ \S 357-72$ (5th ed. 1925) (hereinafter cited as FreemaN); 7 Moore, Federal Practice 263-65 (2d ed. 1955) (hereinafter cited as MooRe) ; Restatenent, JudGMents $\$ 4$, comment $a$ at 20-21 (1942). The terms are often used loosely. A court may be willing to call a judgment void on appeal that it would not consider void on collateral attack. ARNOLD $\mathbb{E}$ JAMES, op. cit. supra note 1 , at 77 n. 12 .

6. See, e.g., Maager v. Hoye, 122 F. Supp. 932 (E.D.N.C. 1954) ; Ex parte Tyler, supra note 5; Batey v. Batey, sipra note 5; 1 BlAcK, JudGMENTs 195 (1891) (hereinafter 
the parties or subject matter makes a judgment void. ${ }^{7}$ It is loosely said that a judgment rendered with such basic jurisdictional omissions is a nullity, equally vulnerable to direct and collateral attack. ${ }^{8}$

However, the ability of a party to question jurisdictional defects when the attack on a prior judgment is branded collateral is subject to severe limitations not present when the attack is a direct one. Recently in collateral proceedings the principle of res judicata has been applied with increasing frequency to bar litigation of alleged jurisdictional irregularities in the original action." A party may be precluded from challenging jurisdiction over the subject matter on the ground that the court rendering the original judgment, having jurisdiction over the parties, either expressly or tacitly determined it had jurisdiction over the subject matter, and that the party, having had a chance to litigate this issue, has already had his day in court. ${ }^{10}$ Similarly, a

cited as Black) ; 1 Freeman 645. See also 7 Moore 260-61; Restatenent, Judgments $\$$ 4 , comment $a$ at 20-21 (1942); note 28 infra and accompanying text.

7. E.g., Lincoln Tavern, Inc. v. Snader, 165 Ohio St. 61,133 N.E.2d 606 (1956) (lack of jurisdiction over person); In re Trevor's Estate, 309 N.Y. 389, 131 N.E.2d 561 (1955) (lack of jurisdiction over subject matter); see Memphis v. Ingram, 195 F.2d 338 (8th Cir. 1952); Anderson v. Anderson, 380 Ill. 435, 44 N.E.2d 54 (1942); 1 BLACK $\$ 171 ; 1$ Freeman 642, 669; Van Fleet, Law of Collateral Attack on Judicial Proceedings $\S 16$ (1892). See also Restatenent, Judgarents $\$ 4$, comment $b$ at $21-22$ (1942).

A void judgment may also result where a court, having once acquired jurisdiction, loses it, Johnson v. Zerbst, 304 U.S. 458 (1938), or commits errors amounting to a denial of due process, Bass v. Hoagland, 172 F.2d 205 (5th Cir.), cert. denied, 338 U.S. 816 (1949), or renders a judgment granting relief not requested by the pleadings, Penn Mut. Life Ins. Co. v. Tittel, 153 Kan. 530, 111 P.2d 1116 (1941) ; Brown v. Brown, 281 S.W.2d 492 (Tenn. 1955).

8. See Duvall v. Duvall, 80 So. 2 d 752 (Miss. 1955); 1 Black 194-95. But see id. at 195. See 1 Freenan 804 .

9. The rationale underlying this doctrine has been stated as follows:

"Every court confronted with a law suit of any kind is under both the necessity and the duty of determining whether or not it has jurisdiction to entertain the suit, and it necessarily has jurisdiction to make this determination. If it determines erroneously that it has jurisdiction, its own erroneous determination does not give it any true jurisdiction of the case as a whole, and its judgment is in general void and therefore subject to collateral attack, but in accordance with the principles which also form the basis for the familiar doctrine of res judicata the judgment may, after it becomes final, be binding upon the parties to the suit although not upon others, and the rights of parties may therefore be limited to appeal, writ of error, petition to vacate, or other methods of direct attack."

Old Colony Trust Co. v. Porter, 324 Mass. 581, 586, s8 N.E.2d 135, 139 (1949).

This doctrine was in large part developed in cases interpreting the "full faith and credit" clause of the Constitution. See Sumner, Full Faith and Credit for Judicial Proccedings, 2 U.C.L.A.L. Rev. 441 (1955); Rashid, The Full Faith and Credit Clause: Collatiral Attack on Jurisdictional Issues, 36 Geo. L.J. 154 (1948) ; Boskey \& Braucher, Jurisdiction and Collateral Attack: October Term, 1939, 40 CoLum. L. Rev. 1006 (1940).

Only a minority of state courts have explicitly applied res judicata to jurisdictional questions. Note, 65 HARv. L. Rev. S18, 855 n.268 (1952).

10. Chicot County Drainage Dist. v. Baxter State Bank, 308 U.S. 371 (1940); Stoll v. Gottlieb, 305 U.S. 165 (1938); In re Estrem's Estate, 16 Cal. 2d 563, 107 P.2d 36 (1940); 
party may be estopped from subsequently questioning the court's jurisdiction over person or res if he has made a special appearance in the original proceeding to contest jurisdiction over his person, ${ }^{11}$ or if he has appeared and participated in an in rem proceeding. ${ }^{\mathbf{1 2}}$ Thus, under the modern view a party in a collateral attack will be free to assert those jurisdictional defects traditionally voiding a judgment $a b$ initio only if the court lacked jurisdiction over his person and he entered no appearance in the original proceeding, or if the court lacked jurisdiction over the res and the complaining party did not participate in the in rem proceeding. ${ }^{13}$

In those cases where a party is not estopped from collaterally attacking a judgment on the basis of jurisdictional defects, his ability to raise such defects in a collateral proceeding is subject to further restrictions not imposed in the case of a direct attack. When a judgment is rendered without jurisdiction over the person or res, the record of the case may be in one of three categories: 1 ) it may affirmatively assert the jurisdiction of the court;14 2) it may omit mention of necessary jurisdictional requirements $;^{15} 3$ ) the judgment roll may manifest lack of jurisdiction or may be contradicted in its assertion of jurisdiction by other parts of the record, such as the return of the sheriff on the summons. ${ }^{16}$ When the judgment under collateral attack is that of a court of a sister state, the court's jurisdiction in the original proceeding is a proper subject of inquiry notwithstanding the condition of the record $;^{17}$ accordingly, extrinsic evidence is admissible to rebut any recital of jurisdictional facts in

In re Lorok, 93 Ohio App. 251, 114 N.E.2d 65 (1952). But see Kalb v. Feuerstein, 308 U.S. 433 (1940).

See, generally, Rashid, supra note 9, at 160-74; Sumner, supra note 9, at 457-59; Boskey \& Braucher, supra note 9, at 1006-12; RestateMrent, JudGMENTs $\$ 10$ (1942); Note, Judgment on Merits as Res Judicata of Jurisdiction over Subject Matter, 49 Y ALE L.J. 959 (1940).

11. Baldwin v. Iowa State Traveling Men's Ass'n, 283 U.S. 522 (1931); see Peri v. Groves, 183 Misc. 589, 50 N.Y.S.2d 300 (Sup. Ct. 1944).

See, generally, Rashid, supra note 9, at 160-63; Sumner, supra note 9, at 455-56; RESTATEMENT, JUDGMENTS $\$ 9$ (1942).

12. Sherrer v. Sherrer, 334 U.S. 343 (1948); Coe v. Coe, 334 U.S. 378 (1948); In re Shomaker's Estate, 93 Cal. App. 2d 616, 209 P.2d 669 (1949) (appearance by attorney); accord, Johnson v. Muelberger, 340 U.S. 581 (1951) (attack by child of party to divorce proceeding).

13. McDonald v. Mabee, 243 U.S. 90 (1917) ; Williams v. North Carolina, 325 U.S. 226 (1945) ; Riley v. New York Trust Co., 315 U.S. 343 (1942).

The modern rule of res judicata has its exceptions. United States v. United States Fidelity \& Guaranty Co., 309 U.S. 506 (1940) (policy of sovereign immunity from suit prevails over principle of res judicata) ; Kalb v. Feuerstein, 30 S U.S. 433 (1940) (exclusive jurisdiction of bankruptcy court prevails over exercise of jurisdiction by state court). See note 84 infra.

14. See 1 FrEENIAN $\$ \S 378-80$.

15. See 1 id. $\$ 383$.

16. See 1 id. $\S \S 381-82$.

17. E.g., Newell v. Newell, 293 P.2d 663 (Idaho 1956); Untermann v. Untermann, 19 N.J. 507,117 A.2d 599 (1955); Taylor v. Taylor, 229 S.C. 92 , 91 S.E.2d 876 (1956); 
the record.18 Where a judgment of a court of limited or inferior jurisdiction is collaterally attacked in a later proceeding in the same state, the complaining party may void the judgment only if lack of jurisdiction appears on the face of the record or if the record fails to allege necessary jurisdictional prerequisites. ${ }^{10}$ Where the judgment was entered by a court of general jurisdiction, it is immune from collateral attack in the courts of the same state unless the judgment roll or other portions of the record demonstrate the absence of jurisdiction. ${ }^{20}$ In all other instances-where the record recites jurisdictional facts ${ }^{21}$ or is silent regarding them ${ }^{22}$ - a judgment rendered by a domestic court of general jurisdiction is conclusively presumed valid as against collateral attack, and no extrinsic evidence is admissible to impeach the record. ${ }^{23}$ When

Peoples Nat'l Bank v. Manos Bros., 226 S.C. 257, 84 S.E.2d 857 (1954) ; Seabron v. Seabron, 133 Cal. App. 2d 374, 284 P.2d 117 (1955).

Inquiry into the jurisdictional facts of a foreign judgment does not violate the "full faith and credit" clause of the Constitution. Thompson v. Whitman, 85 U.S. (18 Wall.) 457 (1873). Moreover, when enforcement of a foreign judgment is sought, the defendant may constitutionally be granted relief on the ground that the judgment was obtained by fraud. Levin v. Gladstein, 142 N.C. 482, 55 S.E. 371 (1906). See GoodrICH, CoNFLICT of Laws 614-17 (3d ed. 1949); Restatearent, Confict of Laws $\$ 440$ (1934).

18. E.g., Seabron v. Seabron, supra note 17 ; Hammond v. Hammond, 45 Wash. 2d 855, 278 P.2d 387 (1954); 1 Brack $\$ 289 ; 1$ Freedran 781. See also Restatement, Judgments $\S 12$, comment $c$ at 71 (1942).

However, a recital of jurisdictional facts in a foreign judgment raises a presumption which must be weighed against any contradictory evidence. Koehne v. Price, 68 A.2d 806 (D.C. Munic. Ct. App. 1949), 49 MrcH. L. Rev. 284 (1950) ; McDougal v. McDougal, 279 S.W.2d 731 (Mo. Ct. App. 1955).

19. See, e.g., Oeth v. Erwin, 6 IIl. App. 2d 18, 126 N.E.2d 526 (1955); State ex rel. Smilack v. Bushong, 93 Ohio App. 201, 112 N.E.2d 675 (1952), aff'd, 159 Ohio St. 259, 111 N.E.2d 918 (1953); State $e x$ rel. Sorensen v. Baird, 201 Ore. 240, 269 P.2d 535 (1954); 1 FREEAIAN $\$ 1 \$-19,855-57 ; 1$ BLACK $\$ \S 279,282,287$. When a court of general jurisdiction exercises special statutory powers it is regarded as an inferior or limited court. Burge v. San Francisco, 41 Cal. 2d 608, 262 P.2d 6 (1953); Oeth v. Erwin, supra (adoption proceedings) ; State ex rel. Smilack v. Bushong, supra (commitment of persons to state mental hospitals); 1 FrEEAIAN $\$ 389 ; 1$ B LACK \& 279.

20. See, c.g., Strother v. Day, 279 S.W.2d 785 (Ky. 1955) ; Westbrook v. Dierks, 292 P.2d 172 (Okla. 1955) ; of. Hicklin v. Edwards, 226 F.2d 410 (8th Cir. 1955). See 1 Freeman $\$ 382 ; 1$ Black $\$ 278$.

21. A recital of jurisdictional facts in the judgment proper may sometimes conflict with other parts of the record. The general rule is that such recitals in the judgment may be impeached on a collateral attack by a contrary showing in the rest of the record. E.g., Williams v. Trammell, 230 N.C. 575, 55 S.E.2d 81 (1949); In re Frankenberg's Estate, 70 Ohio App. 495, 47 N.E.2d 239 (1942). But see note 51 infra and accompanying text; Lackey v. Pulaski Drainage Dist., 4 IIl. 2d 72, 122 N.E.2d 257 (1954) (recitation of jurisdictional facts in court order overcomes defects in record). See Annot., 68 A.L.R. 385 (1930); 1 FreEMAN $\$ 381$.

22. E.g., Olivia v. Suglio, 139 Cal. App. 2d 7, 293 P.2d 63 (1956); see Coryell v. Crawley, 131 N.E.2d 467 (Ind. 1956); 1 FrEEMAN § 383; 1 BLACK $\$ 271$.

23. See Gagnon Co. v. Nevada Desert Inn, Inc., 45 Cal. 2d 448, 289 P.2d 466 (1955); Anderson v. Anderson, 4 Ill. App. 2d 330, 124 N.E.2d 66 (1955); Coryell v. Crawley, supra note 22; Strother v. Day, 279 S.W.2d 785 (Ky. 1955); 1 FreEMAN \$ 378; 1 BlacK § 273; cf. Griggs v. Venerable Sister Mary Help of Christians, 238 S.W.2d 8 (Mo. Ct. 
a judgment is deemed to be directly attacked, jurisdiction is not conclusively presumed, and any jurisdictional facts appearing in the record may be rebutted by extrinsic evidence. ${ }^{24}$

\section{The Identification of an Attack as Direct or Collateral}

Despite the differences in result, the line separating a direct from a collateral attack on a void judgment is often a hazy one, drawn in varying terms by different jurisdictions. The hornbook definition of a direct attack is an attempt to avoid or correct a judgment in a proceeding instituted for that purpose. ${ }^{25}$ In the concrete application of this definition, courts have tended to recognize three major categories of direct attack: $:^{26} 1$ ) a motion for a new

App. 1951) (failure to object to the admission of extrinsic evidence constitutes a waiver of the rule).

There is one major exception, recognized in most jurisdictions, to this generalization. Where the prior judgment was fraudulently procured, and the fraud was of such a nature that it affected the acquisition of jurisdiction or prevented the defendant from presenting his case in court, extrinsic evidence is admissible to impeach the judgment on a collateral attack. E.g., Maager v. Hoye, 122 F. Supp. 932 (E.D.N.C. 1954); Wilson v. Birt, 77 Colo. 206, 235 Pac. 563 (1925); Steffens v. Steffens, 408 I1l. 150, 96 N.E.2d 458 (1951); Hoverstad v. First Nat'l Bank \& Trust Co., 74 N.W.2d 48 (S.D. 1955) ; Sears v. Rusden, 39 Wash. 2d 412, 235 P.2d 819 (1951) (concealment of community property at time of property settlement incorporated into a divorce decree was not the type of fraud that would permit a collateral attack). In some jurisdictions, however, fraud that affects the jurisdiction of the court does not permit a collateral attack unless the judgment is void on its face. Dockery v. Central Ariz. Light \& Power Co., 45 Ariz. 434, 45 P.2d 656 (1935); Bragdon v. Wright, 142 S.W.2d 703 (Tex. Civ. App. 1940). See, generally, 1 FreEmen $\S 308$.

The extrinsic evidence rule is not applicable to strangers to the original action, who may attack a judgment in a collateral proceeding for lack of jurisdiction or for fraud or collusion regardless of the state of the record. Consolidated Rock Products Co. v. Higgins, 54 Cal. App. 2d 779, 129 P.2d 929 (1942); France v. Freeze, 4 Wash. 2d 120, 102 P.2d 687 (1940); cf. Adams v. Adams, 310 Ky. 588, 221 S.W.2d 457 (1949) (contrary to or thodox: standards the court regarded the attack as direct). See 1 FrEEMAN $\$ 318$. However, they may only attack the judgment if it adversely affects their rights. Mitchell v. Auto Owners Indem. Underwriters, 19 Cal. 2d 1, 118 P.2d 815 (1941); In re Hampton's Estate, 55 Cal. App. 2d 543, 131 P.2d 565 (1943) ; Consolidated Rock Products Co. v. Higgins, supra; see 1 FREEMAN $\& 319$.

24. See, e.g., Olivia v. Suglio, 139 Cal. App. 2d 7, 293 P.2d 63 (1956); City of Des Plaines v. Boeckenhauer, 383 Ill. 475,50 N.E.2d 483 (1943); Westbrook v. Dierks, 292 P.2d 172 (Okla. 1955). See, generally, 1 Black $\$ 288$; Annot., 68 A.L.R. 385, 386 (1930).

25. "A direct attack on a judgment is an attempt to avoid, correct, vacate, annul, review, cancel, or set aside the judgment in a proceeding or manner provided by law for such purpose." 49 C.J.S., Judgments § 408 (1947). See also 1 Brack $\$ 252$; VAN FLEET, LAw of Collateral Attack on Judictal Proceedings $§ 2$ (1892); 31 Am. Jur., Judgments \$ 611 (1940).

26. This summary does not specifically refer to the old common law and equitable remedies of audita querela, writ of error coram nobis (or vobis), bill of review, and bill in the nature of a bill of review. For a detailed discussion of the history and characteristics of these ancillary remedies see 7 Moore 33-37; see also 1 BLACK $\$ \$ 299-301 ; 1$ FreEaraN \$\$ 256-57. These remedies were abolished by FED. R. CIV. P. 60(b). See Commentary, 
trial seasonably made before the court rendering judgment, ${ }^{27}$ or an appeal or other proceeding to obtain a nullification of a judgment by a higher court ;28 2) a motion to vacate or set aside a judgment which may be made after the expiration of the time for an appeal or an ordinary motion for a new trial $;^{29}$ 3) a plenary equitable action to vacate or enjoin the enforcement of a judgment. ${ }^{30}$ If the party asserting jurisdictional defects in a prior judgment makes his attack in the form of one of these proceedings, he will avoid the restrictions which would be applicable to a collateral attack.

In order to utilize one of the "direct" attacks as a vehicle for challenging a prior judgment, a party must satisfy the requirements peculiar to the form of proceeding employed. A party may assail any jurisdictional defect by appealing a judgment, but the period for bringing an appeal is sharply curtailed by statute. ${ }^{31}$ A party who has had a default judgment entered against him and who did not receive notice of the proceeding will seldom be apprised of the judgment within the time set for taking an appeal. A motion to vacate a judgment for jurisdictional defects must be brought before the court which

7 Moone 513-16. While they are still retained in some jurisdictions, and are regarded as direct attacks, Schaffer v. Schaleben, 236 S.W.2d 234 (Tex. Civ. App. 1951) ; 1 FreEaraN 519 , they have generally been superseded by proceedings in the form of a motion to set aside a judgment. 1 id. $\$ \$ 256-57 ; 1$ BLACK $\$ \$ 299-301$. See note 29 infra.

27. See, e.g., Fed. R. CIv. P. 59 (motion for a new trial must be made within 10 days after entry of judgment).

An unseasonable motion for a new trial may be regarded as a collateral attack. Garza v. King, 233 S.W.2d 884 (Tex. Civ. App. 1950) (after final judgment and at subsequent term of court).

28. See, e.g., Pena v. Bourland, 72 F. Supp. 290 (S.D. Tex. 1947) ; White v. White, 294 Ky. 563, 172 S.W.2d 72 (1943); Thomas v. Oklahoma Tax Comm'n, 198 Okla. 301, 177 P.2d 498 (1947); See, generally, 1 Black $\$ 252 ; 1$ FreEMran $§ 307 ; 7$ MOORE 261. These sources indicate that other proceedings performing the same function as an appeal, such as a writ of error or certiorari, are also direct attacks.

Mere errors of law in a prior judgment may be challenged only by a form of direct attack fitting within this first category. See, e.g., Carnahan v. Carnahan, 79 Ariz. 371, 375, 290 P.2d 729, 731 (1955); E.x parte Tyler, 152 Tex. 602, 261 S.W.2d 833 (1953); 1 BLACK \& 329 .

29. E.g., Gould v. Richmond School Dist., 58 Cal. App. 2d 497, 136 P.2d 864 (1943); Milton v. Bank of Murray, 305 Ky. 1, 202 S.W.2d 723 (1947) ; Davis v. Rowland, 206 Okla. 257, 242 P.2d 716 (1952); Abel v. Lowry, 68 Nev. 284, 231 P.2d 191 (1951); 1 Freenran $\$ 307 ; 1$ BLACK $\$ 252$. See, e.g., FED. R. CIv. P. 60(b) (motion to vacate a judgment for mistake, newly discovered evidence, or fraud may be brought within a year after the entry of judgment). But see Hicklin v. Edwards, 226 F.2d 410 (8th Cir. 1955) (motion to vacate judgment under rule 60 (b) regarded as collateral attack) (semble).

30. E.g., Wilkin v. Shell Oil Co., 197 F.2d 42 (10th Cir. 1951) ; State ex rel. Morrison v. McCarrell, 80 Ariz. 243, 295 P.2d 1088 (1956) ; Buskirk v. Joseph, $313 \mathrm{Ky} .773,233$ S.W.2d 524 (1950); Brown v. Brown, 281 S.W.2d 492 (Tenn. 1955); 1 Freeman $\$ 308$. But see de Marigny v. de Marigny, 43 So. 2d 442 (Fla. 1949) ; Ward v. Sampson, 395 Ill. 353,70 N.E.2d 324 (1946) (bill of review held collateral); 1 BLACK $\$ 253$.

31. See, e.g., FED. R. CIV. P. 73(a) (usually 30 days from entry of judgment); CAI. Code Crv. P. $\$ 974$ (Deering Supp. 1955) (30 days from rendition of judgment); PA. Stat. AnN. tit. 12, \$ 1136 (Purdon Supp. 1955) (45 days from superior court; three calendar months from court of common pleas). 
originally entered the judgment. ${ }^{32}$ It may be subject to an absolute time limit if a judgment is valid on its face though void in fact. ${ }^{33}$ Moreover, though there be no applicable time limit, the moving party may have to establish that he is not barred by laches for unreasonably delaying his effort to vacate the judgment after being apprised of the alleged jurisdictional errors. ${ }^{34}$ In determining whether the delay was unreasonable, courts will consider whether parties have relied upon the judgment to their detriment. ${ }^{35} \mathrm{~A}$ bill in equity to obtain relief from a prior judgment-the third major form of direct attack - may be brought in any court with equitable powers and at any time, regardless of the condition of the record. ${ }^{36}$ The contesting party must convince

32. See, e.g., Hansen v. McCoy \& McCoy, 221 Iowa 523, 266 N.W. 1 (1936) ; State Highway Comm'n v. Dotson, 307 Ky. 33, 209 S.W.2d 703 (1948) ; cf. Jackson v. Jackson, 199 Ga. 716, 35 S.E.2d 258 (1945).

33. See, e.g., Olivia v. Suglio, 139 Cal. App. 2d 7, 293 P.2d 63 (1956) (6 month limit); Lauer v. Eighth Judicial Dist. Ct., 62 Nev. 78, 140 P.2d 953 (1943) (6 month limit); Ritchie v. Keeney, 181 Okla. 207, 73 P.2d 397 (1937) (3 year limit). In these cases the decision was based upon the court's interpretation of statutes or court rules.

FED. R. CIV. P. $60(\mathrm{~b})$ provides that a motion to vacate a judgment on the ground that it is void must be brought within "a reasonable time." The rule makes no distinction between judgments which are void on their face and those which are not.

Some courts have held that a motion to vacate a void judgment may be made at any time regardless of the condition of the record. Lichter v. Scher, 4 III. App. 2d 37, 123 N.E.2d 161 (1954) ; Langer v. Wiehl, 207 Misc. 826, 140 N.Y.S.2d 298 (Sup. Ct. 1955); Jent v. Brown, 280 P.2d 1005 (Okla. 1955). See also 1 Freearan $\$$ 217, 267.

A motion to vacate a judgment valid on its face if made after an applicable time limit may be regarded as a collateral attack. See, e.g., Wells Fargo \& Co. v. San Francisco, 25 Cal. 2d 37, 152 P.2d 625 (1944); MacVey v. MacVey, 98 A.2d 794 (D.C. Munic. Ct. App. 1953) ; Equitable Life Assur. Soc'y v. Wagner, 2 I11. App. 2d 284, 119 N.E.2d 405 (1954).

34. See, e.g., O'Neal v. B. F. Goodrich Rubber Co., 204 Ark. 371, 162 S.W.2d 52 (1942) ; F. E. Young Co. v. Fernstrom, 31 Cal. App. 2d 763, 79 P.2d 1117 (1938) ; Cummer v. Cummer, 283 IIl. App. 220 (1935). Contra, Green v. Walsh, 5 Ill. App. 2d 535, 126 N.E.2d 398 (1955) ; Langer v. Wiehl, 207 Misc. 826, 140 N.Y.S.2d 298 (Sup. Ct. 1955).

35. See Miller v. McNamara, 135 Conn. 489, 66 A.2d 359 (1949) ; Cummer v. Cummer, 283 I1l. App. 220 (1935) ; Hill v. Walker, 297 Ky. 257, 180 S.W.2d 93 (1944). .

36. See, e.g., Smith v. Jones, $174 \mathrm{Cal} .513,163 \mathrm{Pac} .890$ (1917) ; Lowenthal v. Lowenthal, 130 Cal. App. 2d 527, 279 P.2d 119 (1955) ; Lauer v. Eighth Judicial Dist. Ct., 62 Nev. 78, 140 P.2d 953 (1943); Honeycutt v. Severin, 186 Okla. 509, 98 P.2d 1093 (1940). See note 24 supra and accompanying text. However, independent proceedings in equity may be subject to general limitation statutes. See Smith v. Southern Pine Lumber Co., 256 S.W.2d 893 (Tex. Civ. App. 1953) (four-year limitation on all actions applicable to suit to set aside allegedly void judgment); Kimmell v. Edwards, 194 S.W. 168 (Tex. Civ. App. 1917).

FED. R. Crv. P. 60(b) specifically provides that "this rule does not limit the power of a court to entertain an independent action to relieve a party from a judgment. ..." See Bowen v. Olson, 246 P.2d 602 (Utah 1952).

A party barred by a time lapse from attacking, by a motion to vacate, a judgment valid on its face but void in fact, see note 33 supra, may nonetheless challenge the judgment by a bill in equity. See, e.g., Olivia v. Suglio, 139 Cal. App. 2d 7, 293 P.2d 63 (1956) ; Ransom v. Los Angeles City High School Dist., 129 Cal. App. 2d 500, 277 P.2d 455 (1954). 
the court that, on the basis of the facts of the individual case, equitable intervention is appropriate. ${ }^{37}$ When a default judgment has been entered against a party who claims that the court lacked jurisdiction over his person and that he had no prior notice of the existence of the judgment, a bill in equity will normally be entertained. ${ }^{38}$ Some states add the requirement that the party have a meritorious defense to the original action..$^{39}$

An attack on a prior judgment will be deemed collateral if it fails to fit within a procedural category recognized by a jurisdiction as a form of direct attack. ${ }^{40}$ Since both types seek to invalidate a prior judgment to the same extent, courts will identify an attack as collateral by looking to the legal setting in which it arises. ${ }^{41}$ Thus, a collateral attack has been defined as an attempt to avoid the effect of a judgment in some incidental proceeding not provided by law for the express purpose of attacking it. ${ }^{42}$ Most collateral

37. E.g., In re Hosford's Estate, 26 N.J. Super. 412, 98 A.2d 332 (App. Div. 1953); Carver v. Huff, 283 S.W.2d 317 (Tex. Civ. App. 1955).

Freedom from laches is usually a prerequisite to granting equitable relief from a judgment valid on its face but void in fact. Lamar v. Houston, 183 Miss. 260, 184 So. 293 (1938) ; Katz v. Swanson, 147 Neb. 791, 24 N.W.2d 923 (1946); Alonso v. Bowers, 222 La. 1093, 64 So. $2 \mathrm{~d} 443$ (1953). Contra, In re Estate of Gray, 162 Ohio St. 384, 123 N.E.2d 408 (1954).

Relief in equity may also be conditioned on the absence of adequate legal remedy. $C f$. Duran v. Adjustment Bureau, Inc., 287 P.2d 441 (Colo. 1955) ; Kerber v. Alt, 275 S.W.2d 607 (Mo. Ct. App. 1955). Under this doctrine an equitable action will apparently not be entertained if the contesting party could maintain a motion to vacate before the court rendering the judgment.

38. See, c.g., Hawkins v. Sanders, 260 Ala. 585, 72 So. 2d 81 (1954); Lowenthal v. Lowenthal, 130 Cal. App. 2d 527, 279 P.2d 119 (1955); Honeycutt v. Severin, 186 Okla. 509, 98 P.2d 1093 (1940); Culwell v. Culwell, 23 Tenn. App. 389, 133 S.W.2d 1009 (1939). But sec Johnson v. First Nat'l Bank, 223 F.2d 31 (10th Cir. 1955) (court in equitable proceeding will not look beyond the record even though direct attack).

39. See, c.g., Murphree v. International Shoe Co., 246 Ala. 384, 20 So. $2 \mathrm{~d} 782$ (1945); Kupfer v. MacDonald, 19 Cal. 2d 566, 122 P.2d 271 (1942); Honeycutt v. Severin, supra note 38; Garza v. King, 233 S.W.2d 884 (Tex. Civ. App. 1950). Contra, Martin v. Slagle, 178 Tenn. 121, 156 S.W.2d 403 (1941). There is no requirement of a meritorious defense on a motion to vacate a void judgment. Hicklin v. Edwards, 226 F.2d 410 (8th Cir. 1955).

40. Courts sometimes refer to a third form of attack-the indirect attack. The use of this term serves only to confuse the problem as sometimes indirect seems to be synonymous with collateral, Thomas v. Marvins Credit, Inc., 81 A.2d 340 (D.C. Munic. Ct. App. 1951) (motion to vacate judgment of condemnation based on invalidity of a prior judgment), and sometimes it seems to be distinct from collateral, Renshaw v. Happy Valley Water Co., 114 Cal. App. 2d 521, 250 P.2d 612 (1952) (cross-complaint in quiet title action seeking equitable reformation of prior judgment; see note 60 infra). See 1 FrEENAN 604-05.

41. 1 FreEMAN 609. See also notes 55-61 infra and accompanying text.

42. "A collateral attack is an attempt to avoid, defeat, or evade a judgment, or to deny its force and effect, in some incidental proceeding not provided by law for the express purpose of attacking it." 49 C.J.S., Judgntents $\$ 408$ (1947). See also VAN FLEEr, Law of Collateral Attack on Judictal Proceedings $\$ 3$ (1892); 1 Black $\$ 252 ; 31$ AM. JUR., Judgments § 611 (1940). 
attacks fall into, two broad classes:43 1 ) where the successful plaintiff in the original proceeding attempts to enforce his judgment, or some right derived from that judgment, in a subsequent action, and the defendant pleads the invalidity of the prior judgment; ${ }^{44}$ 2) where the unsuccessful defendant in the original proceeding seeks to assert some claim of his own, but can do so only by avoiding the prior judgment pleaded as a bar to his action. ${ }^{45}$

The foregoing criteria for distinguishing collateral from direct attacks have been supplemented by a variety of formulas. Many states adhere to the doctrine that an independent proceeding which would constitute a direct attack if the sole relief sought were invalidation of a prior judgment will be deemed a collateral attack if the party seeks to set aside the judgment as a means of obtaining additional requested relief. ${ }^{46}$ Thus, in Turner $v$. Bell ${ }^{47}$ plaintiff brought an equitable action to declare void ab initio a local court's decree of divorce from her former husband, since deceased, and to have decreed to her homestead and dower rights in his estate. The divorce was assailed on the grounds of fraud and lack of jurisdiction. The court labeled the proceeding a collateral attack on a domestic decree of divorce, which could be maintained

43. In certain proceedings attacks on a prior judgment are always considered collateral. They include petitions for writs of habeas corpus, Hodge v. Huff, 140 F.2d 686 (D.C. Cir.), cert. denied, 322 U.S. 733 (1944); Ex parte La Rocca, 154 Tex. 618, 282 S.W.2d 700 (1955); Ex parte Tyler, 152 Tex. 602, 261 S.W.2d 833 (1953); 1 FrEEMAN $\$ 316$; 1 BLACK $\$ 254$, requests for declaratory judgments, Shattuck v. Shattuck, 67 Ariz. 122, 192 P.2d 229 (1948) ; Mid-Continent Petroleum Corp. v. Frazier, 167 Kan. 113, 204 P.2d 732 (1949), and contempt proceedings, Maggio v. Zeitz, 333 U.S. 56 (1948); 1 FREEMMN $\S 311$.

44. E.g., Williams v. Steamship Mut. Underwriting Ass'n, 45 Wash. 2d 209, 273 P.2d 803 (1954) (suit to enforce a judgment); Hume v. Ricketts, 69 Wyo. 222, 240 P.2d 881 (1952) (action to revive a judgment) ; Higginson v. Schoenenman, 190 F.2d 32 (D.C. Cir. 1951) (suit for balance due on final judgment) ; Thomas v. Marvins Credit, Inc., 81 A.2d 340 (D.C. Mun. Ct. App. 1951) (condemnation proceeding under writ of garnishment); Kutz Canon Oil \& Gas Co. v. Harr, 56 N.M. 358, 244 P.2d 522 (1952) (action to quiet title based on prior decree).

45. Cox v. MacKenzie, 70 Ariz. 308, 219 P.2d 1048 (1950) (action against administrator for erroneous averment in final report after entry of probate decree); Strother v. Day, 279 S.W.2d 785 (Ky. 1955) (suit to set aside deed and transfer of personal property to defendant under probate decree); Westbrook v. Dierks, 292 P.2d 172 (Okla. 1955) (suit to quiet title to property subject of prior quiet title action) ; Sears v. Rusden, 39 Wash. 2d 412, 235 P.2d 819 (1951) (action to obtain interest in property disposed of in divorce settlement).

46. E.g., Dockery v. Central Ariz. Light and Power Co., 45 Ariz. 434, 45 P.2d 656 (1935) (action to void order of probate court and for damages); Mitchell v. Village Creek Drainage Dist., 158 F.2d 475 (8th Cir. 1946) ; Cassady v. Norris, 118 Ark. 449, 177 S.W. 10 (1915) ; Hoverstad v. First Nat'l Bank \& Trust Co., 74 N.W.2d 48 (S.D. 1955). See 1 FreEMan 606-08.

"[W] here an action has for its primary purpase the obtaining of independent relief, and the vacating or setting aside of a judgment is merely incidental thereto, such action is not a direct, but a collateral, attack on the judgment." Dockery v. Central Ariz. Light and Power Co., supra at 445, 45 P.2d at 660.

47. 198 Tenn. 232, 279 S.W.2d 71, cert. denied, 350 U.S. 842 (1955). 
only if the record on its face showed the decree to be void. The court reasoned that the attack was collateral because the main purpose of plaintiff's action was not to set aside the decree but to establish rights in the property of the deceased. ${ }^{48}$

The Texas law on direct and collateral attack contains unique features. With the exception of appeals and other forms of appellate review, an attack will not be considered direct unless brought before the court rendering the original judgment. ${ }^{40}$ Thus Texas courts, unlike other jurisdictions, will not entertain an independent equitable action to set aside the judgment of another domestic court by the demonstration of jurisdictional defects through extrinsic evidence. $^{50}$ This restriction is supplemented by the doctrine that recitation in the judgment roll of proper personal service is deemed conclusive as against attack in another court, and may not be contradicted even by other facts appearing elsewhere in the record. ${ }^{51}$

Some courts have asserted in dicta that a collateral attack is " an attempt to impeach a judgment by matters dehors the record in an action other than that in which it was rendered.' "52 As a means of distinguishing collateral from direct attacks, such a standard would lead to results sharply at variance with present law. If an attack is branded collateral whenever extrinsic evidence is sought to be introduced, and if the court adheres to the established doctrine that extrinsic evidence is inadmissible on a collateral attack to contradict the record of a domestic judgment, 53 the only possible conclusion would be that a domestic judgment valid on its face could never be set aside in a later independent proceeding. While the above definition of a collateral attack typifies the confused judicial thinking pervading this subject, it has not altered the

48. "[I]f the action or proceeding has an independent purpose and contemplates some other relief or result, although the overturning of the judgment may be important, or even necessary to its success, the attack upon the judgment is collateral.' "Id. at 241, 279 S.W.2d at 75.

49. E.g., Pena v. Bourland, 72 F. Supp. 290 (S.D. Tex. 1947) ; Holmes v. Jackson, 200 S.W.2d 276 (Tex. Civ. App. 1947) ; Steward v. Adams, 171 S.W.2d 180 (Tex. Civ. App. 1943); Waples Platter Co. v. Miller, 139 S.W.2d 833 (Tex. Civ. App. 1940). The basis for these decisions is TEx. Rev. Civ. Stat. art. 4656 (Vernon Supp. 1956).

There is some evidence that this doctrine is followed outside Texas. See Hume v. Ricketts, 69 Wyo. 222, 240 P.2d 881 (1952).

50. Switzer v. Smith, 300 S.W. 31, 68 A.L.R. 377 (Tex. Com. App. 1927) (defendant in suit to foreclose a judgment lien brought a cross bill to enjoin plaintiff from enforcing his judgment) ; Holmes v. Jackson, supra note 49 ; Steward v. Adams, supra note 49.

51. E.g., Shelton v. Belknap, 275 S.W.2d 174 (Tex. Civ. App.), rev'd on other grouids, 282 S.W.2d 682 (Tex. 1955) ; Switzer v. Smith, supra note 50; Graham v. Seale, 221 S.W.2d 353 (Tex. Civ. App. 1949) ; Litton v. Waters, 161 S.W.2d 1095 (Tex. Civ. App. 1942). See 25 TEx. Jur. § 328 (1933).

52. Clark v. Deschamps, 109 Cal. App. 2d 765, 769, 241 P.2d 681, 683 (1952) ; see County of Fresno v. Roberson, Martin and Co., 124 Cal. App. $2 d$ 888, 269 P.2d 252 (1954) ; Juday v. Lantz, 124 Ind. App. 552, 117 N.E.2d 382 (1954) ; Sears v. Rusden, 39 Wash. 2d 412, 235 P.2d 819 (1951). See also 1 Freenan 608-09; VAN Fieet, LAw of Collateral Attack on Judicial Proceentngs $\$ 4$ (1892).

53. See text at notes 21-23 supra. 
substantive law, since the statement has been made in respect of proceedings which would be deemed collateral under orthodox standards..$^{54}$

\section{Irrationalities of Present LaW}

The criteria which courts have evolved for identifying direct and collateral attacks have led to unsound results. Under existing law the ability of a party to question defects in a prior judgment depends upon the skill of his lawyer in following illogical procedural steps. For example, if a party brings a suit to quiet title, the success of which depends upon his voiding a prior judgment pleaded as a bar to his action, the attack on the former judgment will be labeled collateral, and the judgment will stand if valid on its face. ${ }^{55}$ Similarly, if such a party brings an action to annul the prior judgment and also requests the court to quiet title in property subject to the judgment, it may be held that the prayer for additional relief converts the proceeding into a collateral attack, and prevents impeachment of the record of the former judgment by extrinsic evidence..$^{56}$ In contrast, if the complaining party initially brings an independent action to set aside the prior judgment and later brings a separate suit to quiet title to the property, his action will fit within the definition of a direct attack and he will avoid the limitations which would be applicable to the other methods of proceeding. ${ }^{57}$

Such irrational distinctions vividly illustrate how form has prevailed over substance in this area of the law. If the court would entertain an independent action to set aside a prior judgment, it is illogical to restrict a party's attempt to vacate a judgment when brought in the context of a proceeding not directed exclusively to that purpose. In both cases the party desires equally to annul the former judgment; ${ }^{58}$ he should not pay a penalty if he combines his attack with a prayer for other judicial relief.

The extent to which courts have been dominated by niceties of pleading in classifying an attack on a judgment is illustrated by a recent Connecticut case.59 Plaintiff brought an action to collect on a judgment; defendant's answer contained a special defense that he was not served with process in the original proceeding and had no notice of its pendency. In affirming judg-

54. E.g., Clark v. Deschamps, 109 Cal. App. 2d 765, 241 P.2d 681 (1952), was an action for a declaratory judgment, one which is always regarded as collateral. See note 43 supra.

55. E.g., Svetina v. Burelli, 87 Cal. App. 2d 707, 197 P.2d 562 (1948) ; Whitely v. Mills, 239 Iowa 80, 29 N.W.2d 541 (1947); Hinton v. Stanton, 124 Mont. 534, 228 P.2d 461 (1951); Westbrook v. Dierks, 292 P.2d 172 (Okla. 1955).

56. Bates v. Mitchell, 67 Ariz. 151, 192 P.2d 720 (1948) ; Cassady v. Norris, 118 Ark. 449, 177 S.W. 10 (1915); Moyes v. Moyes, 60 Idaho 601, 94 P.2d 782 (1939). Contra, Newsome v. Hall, $290 \mathrm{Ky} .486,161$ S.W.2d 629 (1942).

57. See Moyes v. Moyes, supra note 56, at 610, 94 P.2d at 786.

58. See Turner v. Bell, 198 Tenn. 232, 241, 279 S.W.2d 71, 75, cert. denied, 350 U.S. 842 (1955) ; O'Neill v. Potvin, 13 Idaho 721, 93 Pac. 20 (1907). See 1 FreEMan 607-08.

59. Lamson Lumber Co. v. Hoer, 139 Conn. 294, 93 A.2d 143 (1952), noted in 27 CoNn. B.J. 383 (1953). 
ment for plaintiff, the court held that defendant could not introduce extrinsic evidence to show lack of jurisdiction, because his attack on the former judgment was collateral. The court emphasized that defendant had done no more than allege as a defense to the present claim that the prior judgment was void. The court asserted in dicta that extrinsic evidence would have-been admissible if defendant had filed a cross-complaint praying that the judgment be invalidated or plaintiff be enjoined from enforcing it. ${ }^{60}$ Why the court should have penalized defendant for not taking additional procedural steps is difficult to comprehend. The affirmative defense raised the same issues as would have been tendered by a cross-complaint; 61 in both cases, defendant would seek to defeat the present action by demonstrating jurisdictional defects in the prior judgment. Thus defendant was barred from making an attack which would have been perfectly proper if he had filed additional pleadings presenting the same substantive questions.

When a court precludes an attack on a prior judgment which it would have allowed had an alternative procedural route been followed, it may foreclose the party seeking to invalidate the judgment from ever obtaining an adjudication of its alleged defects. Since the contesting party was initially barred from litigating the validity of the judgment by the classification of his attack as collateral, he has not had his day in court on this issue; accordingly, he will probably not be barred by res judicata from directly attacking the judgment

60. 139 Conn. at 296-97, 93 A.2d at 145 .

The court thus followed the holding of some jurisdictions that equitable relief from a void judgment may be sought not only by an independent proceeding instituted for that purpose, but also by a counterclaim or cross-complaint, in an action to enforce the contested judgment. See Barrett v. Stone, 123 Ind. App. 191, 108 N.E.2d 201 (1952); Bowen v. Olson, 246 P.2d 602 (Utah 1952); Sutherland v. Rasnake, 169 Va. 257, 192 S.E. 695 (1937); cf. Renshaw v. Happy Valley Water Co., 114 Cal. App. 2d 521, 250 P.2d 612 (1952). Contra, Haugan v. Yale Oil Corp., 124 Mont. 1, 217 P.2d 1084 (1950). See, generally, 1 FreEaran 616.

Even if a court is willing to permit a direct attack by way of counterclaim, such a concession may be utilized only if the attacking party is the defendant in the proceeding in which the attack on the prior judgment arises. If the attacking party is the plaintiff in such a proceeding and amends his complaint to request relief from a void judgment, in addition to the relief originally sought, his attack may be held collateral under the "independent purpose" rule. See notes 46-48 supra and accompanying text.

Contrary to the holding in the Lamson case, there is some authority for the proposition that the invalidity of a judgment valid on its face may be pleaded in the answer as a defense. Wilson v. Birt, 77 Colo. 207, 235 Pac. 563 (1925); Kingsborough v. Tousley, 56 Ohio St. 450, 47 N.E. 541 (1897). See note 67 infra. Contra, Williams v. Steamship Mut. Underwriting Ass'n, 45 Wash. 2d 209, 273 P.2d 803 (1954).

61. Hallack v. Loft, 19 Colo. 74, 34 Pac. 568 (1893); Kingsborough v. Tousley, supra note 60 ; notes $66-67$ infra and accompanying text.

"If the matter contained in the replication had been set forth in the complaint, it would, without question, have been a proper mode of seeking equitable relief in connection with the claim sued on. That the facts impeaching the former judgment were first set forth in the replication was a matter of form, rather than substance." Hallack v. Loft, supre at 82,34 Pac. at 571. 
in a later independent proceeding. ${ }^{62}$ However if the party, having unsuccessfully attempted to attack the judgment in the course of a prior action, brings a motion to vacate or a bill in equity, the court may refuse to allow such an attack on the ground of laches or the absence of requirements justifying equitable relief. ${ }^{63}$ For the court may reason that the party, though apprised of the assertion of rights under the judgment at an earlier date, neglected to attack it directly at that time; therefore his present equities are fatally diluted and his standing to attack destroyed.

If the court is willing to permit a direct attack after a collateral one on the same judgment, the contesting party will not be permanently denied an opportunity to present his case. However, he will be forced to incur the expense and inconvenience of instituting a separate action. In addition, by refusing to allow the attack when originally made, the court has necessitated two proceedings when all the issues could have been conveniently handled in one. Such a result is in striking contrast to the modern procedural trend of eliminating multiplicity of suits wherever possible, and of litigating all pending controversies concerning the same parties in a single action..$^{64}$

Dissatisfied with the illogical consequences inherent in the prevailing concepts of direct and collateral attack, a handful of jurisdictions have deviated from the established doctrines in this area. In New York extrinsic evidence is admissible in a traditionally collateral attack of a domestic judgment to show lack of jurisdiction. ${ }^{65}$ Ohio courts follow a different line of reasoning to achieve

62. See Smith v. Jones, 174 Cal. 513, 163 Pac. 890 (1917); Winn v. Torr, 27 Cal. App. 2d 623, 81 P.2d 457 (1938).

However, a prior direct attack to invalidate a judgment is res judicata on the jurisdictional question. American Surety Co. v. Baldwin, 287 U.S. 156 (1932), 42 YALE L.J. 427 (1933) ; American Surety Co. v. Mosher, 48 Ariz. 552, 64 P.2d 1025 (1936) ; Bernhard v. Idaho Bank \& Trust Co., 21 Idaho 598, 123 Pac. 481 (1912).

63. See notes $34,35,37$ supra and accompanying text.

64. This trend is evidenced by the adoption of procedural rules providing for liberal joinder of causes of action, and for compulsory and permissive counterclaims. See $F_{E D}$. $R$. Crv. P. 13(a), 13(b), 18(a) ; Clark, Code Pleading 462-68, 637-48 (2d ed. 1947). Under rule 18(a) a party may join "as many claims either legal or equitable or both as he may have against an opposing party." Failure to plead a claim under the compulsory counterclaim provision may bar a later action on the counterclaim on the ground that the original judgment is res judicata. Biaett v. Phoenix Title \& Trust Co., 70 Ariz. 164, 217 P.2d 923 (1950). See Moore, Federal Rules 110-11 (1956); ClARK, op. cit. supra at 648.

If a judgment is void on its face, failure to plead its invalidity in a counterclaim may also preclude a later attack on the judgment. See Mitchell v. Village Creek Drainage Dist., 158 F.2d 475 (8th Cir. 1946).

65. Ferguson v. Crawford, 70 N.Y. 253, 26 Am. Rep. 589 (1877); In re Spring's Estate, 280 App. Div. 642, 117 N.Y.S.2d 356 (3d Dep't 1952); Campbell v. Jackson, 111 N.Y.S.2d 446 (Sup. Ct. 1952); Dye v. Dye, 93 N.Y.S.2d 95 (Sup. Ct. 1949).

There is some evidence that the New York doctrine has been accepted elsewhere. See Johnson v. Bruflat, 45 S.D. 200, 186 N.W. 877 (1922); Moore v. Connecticut Gen. Life Ins. Co., 71 S.D. 512, 26 N.W.2d 691 (1947). In Illinois there are apparently two lines of authority: Janove v. Bacon, 6 Ill. 2d 245, 128 N.E.2d 706 (1955); In re Young's Estate, 414 Ill. 525, 112 N.E.2d 113 (1953); Espadron v. Davis, 380 Ill. 199, 43 N.E.2d 962 (1942), permitting extrinsic evidence on a collateral attack, and Anderson v. Anderson, 
the same result; they will label as direct any attack against a prior domestic judgment for want of personal jurisdiction over the defendant. ${ }^{66}$ Thus, even though the attack arises by way of defense to an action to enforce the judgment, the contesting party may introduce evidence to contradict the assertion of jurisdiction in the record of the original proceeding. ${ }^{67}$ The rationale for the New York and Ohio doctrines is that, under the merger of law and equity, a party should not be prevented from proving any defense which would serve as a basis for an independent equitable action. ${ }^{68}$ In Kentucky an attack on a prior domestic judgment in an independent proceeding has been classified direct, even though plaintiff sought additional relief beside the vacating of the judgment. ${ }^{69}$ Rejecting the majority view, Kentucky courts have reasoned that a prayer for incidental relief should not operate to convert a direct attack into a collateral one, since plaintiff would be awarded the requested relief only if successful in voiding the judgment. ${ }^{70}$

While the foregoing variations on established principles have enabled courts to reach sensible results in the cases in which they have been applied, they do not present a complete solution to the irrationalities arising from the direct-collateral dichotomy. Even in those jurisdictions which, regardless of the procedural form the attack assumes, allow the introduction of extrinsic evidence to show jurisdictional defects voiding a judgment, courts are still controlled by whether an attack is direct or collateral when an infirmity

4 IIl. App. 2d 330, 124 N.E.2d 66 (1955) ; In re Leichtenberg's Estate, 5 IIl. App. 2d 336, 125 N.E.2d 277 (1955), prohibiting extrinsic evidence. See, generally, 1 FREEMAN $\$ 377$; 1 BLACK $\$ 274$.

66. E.g., In re Frinzl, 152 Ohio St. 164, 87 N.E.2d 583 (1949); Lenz v. Frank, 152 Ohio St. 153, 87 N.E.2d 578 (1949) ; Kingsborough v. Tousley, 56 Ohio St. 450,47 N.E. 541 (1897); see Haag v. Meffley, 89 Ohio App. 471, 103 N.E.2d 37 (1951). See also 23 OHIO JUR. § 999 (1932).

67. E.g., Conner v. Miller, 154 Ohio St. 313, 96 N.E.2d 13 (1950), 12 Oнго St. L.J. 482 (1951); Kingsborough v. Tousley, supra note 66 . See note 60 supra and accompanying text.

68. Ferguson v. Crawford, 70 N.Y. 253, 267, 26 Am. Rep. 589, 600 (1877) ; Kingsborough v. Tousley, 56 Ohio St. 450, 462, 47 N.E. 541, 544 (1897).

69. Taylor v. Howard, $306 \mathrm{Ky} .407,208$ S.W.2d 73 (1948) (action to set aside a judgment, to cancel a deed, for an allotment of dower, and for an accounting); see Buskirk v. Joseph, $313 \mathrm{Ky} .773,233$ S.W.2d 524 (1950) (action to set aside court order and cancel deeds) ; State Highway Comm'n v. Dotson, 307 Ky. 33, 209 S.W.2d 703 (1948) (action for reformation of a deed); Newsome v. Hall, $290 \mathrm{Ky} .486,161$ S.W.2d 629 (1942) (suit to void a judgment and set aside an execution sale and de'ed).

70. "It appears to us that appellant is attempting to place undue emphasis upon the incidental rather than upon the more important and significant relief sought herein. The primary and important relief sought is the cancellation of the deed and the vacation of the judgment. The other relief sought is incidental thereto. The attack made here was as direct as any attack could be made. ... The fact that other consequential or additional relief was sought in no way operates to destroy the directness of the principal attack."

Taylor v. Howard, supra note 69 , at 410, 208 S.W.2d at 74. But see notes $46-48,56$ supra and accompanying text. 
is asserted which makes a judgment voidable but not void. ${ }^{71}$ For hombook law provides that nonjurisdictional defects warranting the setting aside of a voidable judgment may be raised only on direct attack ;2 $^{\mathbf{2}}$ those courts which have sought to revamp the prevailing concepts in the field of attacking judgments have liberalized the law only in those cases where the contesting party seeks to show that the judgment is void. Thus, if an Ohio court feels that the asserted defect makes a prior judgment voidable but not void, it will not entertain an attack considered collateral, even though the contesting party could have raised the defect in a direct attack if he had followed alternative procedural steps. $^{73}$

Moreover, the jurisdictions which have professed abandonment of traditional restrictions on a party's efforts to void a judgment have not consistently adhered to the enlighted doctrines they have announced. For example, in Kentucky a prayer for additional relief may at times be held to convert an attempt to void a judgment into a collateral attack, with the consequent exclusion of extrinsic evidence. ${ }^{74}$ And in Ohio a court has applied the "collateral" stamp even to a proceeding to vacate a judgment for jurisdictional defects. ${ }^{75}$ Responsible for such digressions is the fact that no jurisdiction, regardless of any reforms it has inaugurated, has abandoned use of the directcollateral terminology. So long as this conceptual dichotomy exists, the litigant is exposed to the risk that the courts will unpredictably attach one label or the other in a given situation.

\section{A Suggested Revision of the Law of Attacking. Judguents}

Any reformulation of the law of direct and collateral attack must recognize the salient policies to be served in this field. These policies may be reduced to three major categories:

1) the protection of judgments in order to secure termination of litigation and the finality of judicial determinations ;6 $^{\mathbf{7 6}}$

71. In re Chase Nat'l Bank, 283 N.Y. 350, 28 N.E. 2 d 868 (1940); Kurzweil v. Story \& Clark Piano Co., 95 Misc. 484, 159 N.Y. Supp. 231 (City Ct. 1916) ; Tari v. State, 117 Ohio St. 481, 159 N.E. 594 (1927) ; 23 Ohio Jur. $\$ \$ 520$, 983 (1932). But sec Dobson v. Pearce, 12 N.Y. (2 Kernan) 156 (1854) (defendant fraudulently prevented from presenting his case in the original proceeding); Brone v. Golde, 267 N.Y. 284, 196 N.E. 60 (1935).

72. E.g., Davis v. Rudolph, 242 Iowa 589, 45 N.W.2d 886 (1951); Inhabitants of Lincolnville v. Perry, 150 Me. 113, 104 A.2d 884 (1954). See cases cited note 6 supra and accompanying text. 1950).

73. See Horovitz ex rel. Ohio Colprovia Co. v. Shafer, 94 N.E.2d 201 (Ohio Ct. App.

74. White v. White, $294 \mathrm{Ky} .563,172$ S.W.2d 72 (1943) (action to void judgment, to obtain sale of land and division of proceeds); McFarland v. Hudson, $262 \mathrm{Ky}$. 183, S9 S.W.2d 877 (1936) (action to void a judgment, to recover property, and to have a lien declared in plaintiff's favor); cf. Anderson v. Kerr, 240 S.W.2d 91 (Ky. 1951).

75. Moor v. Parsons, 98 Ohio St. 233, 120 N.E. 305 (1918).

76. Lancaster v. Wilson, $68 \mathrm{Va}$. (27 Gratt.) 624, 629 (1876). See 1 Freedran 602-03, $789 ; 1$ BLACK $§ 245$. 
2) an opportunity for each individual to present his case in court ;7

3) the protection of the interests of bona fide purchasers who have relied upon the validity of a judgment. ${ }^{78}$

The present law of direct and collateral attack reconciles these values inadequately. The collateral-direct distinction is an anomalous exception to modern rules of pleading and practice. ${ }^{79}$ One justification for carving out the restrictive category of collateral attack was to help keep the courts free from congestion and confusion incident to subsequent re-examination of final judgments. ${ }^{80}$ Yet this end is hardly served if the effect of classifying an attack as collateral is to force the party to commence an independent proceeding, consuming court time and facilities to a greater extent than if the attack had originally been allowed in connection with another action. ${ }^{81}$ Furthermore, such procedural bars may preclude a party from raising a defect altogether regardless of the merits of his claim. This last result may serve the first and third values outlined above, but at the price of sacrificing the second. 82 To obtain the optimum reconciliation of the second value with the first and third, a party's standing to invalidate a judgment should be predicated not upon the procedural formalities of the attack, but upon the failure of a prior opportunity to raise the defect and the lack of reliance on the judgment by innocent parties.

In order to cure existing weaknesses, the following changes in the law of attacking judgments are proposed. Since rules of collateral attack are not based on statute, most of the changes suggested may be effected by decisional law.

1) The distinction between a direct and collateral attack should be abolished.

2) Regardless of the procedural context in which the attack arises, a party's attempt to set aside a prior final judgment should be permitted:

a) in the case of a domestic or foreign judgment, if the reason for seeking to set aside the judgment is such that the court would under existing law entertain an independent action for equitable relief from the effect of the judgment; or

77. 1 id. at 343 . See, generally, 1 id. $\$ 276 ; 1$ FREEMAN $\$ \$ 377-77 a$.

78. Lancaster v. Wilson, 68 Va. (27 Gratt.) 624, 629 (1876). See 1 FreEMAN 791-92; 1 BLACK $\$ \$ 245,276$.

79. See note 64 supra and accompanying text.

80. 1 Freearan $\$ \S 305,376 ; 1$ Black $\$ \S 245,276$; Van Fleet, Law of Collateral Attack on Judictal Proceedings 3 (1892).

81. See Hamilton v. Waters, 93 Cal. App. 2d 866, 210 P.2d 67 (1949). X brought an action for unlawful detainer against $Y$ and recovered a judgment. Under this judgment a writ of possession was issued to the marshal and $Y$ was evicted. $Y$ then sued $X$ for damages for wrongful eviction claiming no service in the unlawful detainer suit. Y's action was dismissed as collateral and $\mathrm{Y}$ was instructed that his remedy was in equity to have the judgment set aside.

82. However, if a party precluded from raising defects on a collateral attack is later able to bring a direct attack, see notes 61,64 supra and accompanying text, the first and third values will be but temporarily served. 
b) in the case of a domestic judgment, if the reason for seeking to set aside the judgment is such that the court which rendered the judgment would presently entertain a motion to vacate.

3) If the party attacking the judgment qualifies under 2(a) or (b), he should be permitted to introduce extrinsic evidence, regardless of the state of the record of the attacked judgment.

4) In determining whether relief should be granted under $2(a)$ or (b), the court should apply the same standards and limitations as would have determined the granting of relief had the contesting party in fact brought an independent action or motion to vacate.

5) These principles should be applied with equal force whether the asserted defect in the prior judgment is such as would make the judgment void or merely voidable.

6) Except where the attack is by appeal, a party should be barred from asserting lack of jurisdiction over person, res or subject matter unless he did not specially appear or otherwise participate in the original action and the court lacked jurisdiction over his person or the res. ${ }^{83}$

7) A party with knowledge of the existence of a judgment should be barred from asserting any of its defects if he has had a reasonable opportunity to raise the defect in an appropriate proceeding, and if persons who have relied upon the validity of the judgment would suffer hardship were it set aside.

8) The bona fide purchaser of property transferred as a result of a judgment should be protected as against parties asserting defects in the judgment if the judgment is voidable but not if it is void, unless the circumstances are such that (7) governs.

Adoption of the foregoing rules will enable courts to reach decisions based upon sound policy considerations, and will also import certainty and predictability into this area of the law. Rules (1) to (5) are designed to ensure that a party against whom a void or voidable judgment has been rendered will not be precluded from contesting the judgment because of his failure to follow the procedural steps which the law now demands. Accordingly, a party seeking to invalidate a judgment in any legal setting will be afforded the same rights as he would enjoy had he brought an independent equitable action before the court in which the attack arises. In addition, even though the defect in a prior domestic judgment is not such as would warrant equitable relief, a party will still be permitted to raise it if, under statutory and common law, he could bring a motion to vacate before the court which originally entered the judgment. These provisions, while not expanding the substantive rights presently available in an appropriate form of attack, will serve to eliminate multiplicity of actions by enabling a claim against a judgment to be adjudicated without the institution of a new proceeding.

While the contexts within which a judgment may be challenged are significantly broadened under the new rules, the contesting party's ability to raise a defect will be subject to restriction if he has already had an adequate oppor-

83. Where the court has jurisdiction over the parties, it has the power to deternime its jurisdiction over the subject matter. See note 10 supra and accompanying text. 
tunity to present his claim in court. Rule (6) incorporates modern views on res judicata $;^{84}$ it prevents (except by appeal) the assertion of jurisdictional defects where a party has been afforded the chance to make his objection in the initial litigation. The rule assumes that a party will have notice of the original proceeding, and will accordingly be apprised of his opportunity to raise jurisdictional errors, if the court had jurisdiction over his person or if he entered and took part in the action. Even where a default judgment has been rendered against a party over whom the court lacked jurisdiction, the defendant may be barred under rule ( 7 ) from making any attack on the judgment if he gained notice of its existence and could have reasonably instituted a proceeding to assert the defect. ${ }^{85}$ This limitation will be invoked if any party has acted in reliance upon the judgment and would be adversely affected by its invalidation. Thus, rules (6) and (7) will foster the conclusiveness of judgments by forbidding any attack after the injured party has been given a reasonable chance to assert his rights.

Even where bona fide purchasers are not safeguarded by the applicability of rule (6) or (7), their interests may still be protected under rule (8) if the judgment through which their rights were derived is voidable, but not if it is void. This difference in protection accorded bona fide purchasers under void and voidable judgments - a distinction which is the basis of present law ${ }^{86}$ seems to effect an equitable balancing of interests. Where a void judgment has

84. See text at notes 9-13 supra.

The Restatement of Judgments recognizes that there will be circumstances where a court's determination of jurisdiction over the subject matter should not be given the effect of res judicata. Those circumstances exist when the "policy underlying the doctrine of res judicata is outweighed by the the policy against permitting the court to act beyond its jurisdiction." The Restatement gives as an example a divorce decree entered by a justice of the peace without jurisdiction even though the defendant appeared and litigated the question of jurisdiction. Restatenent, Judgarents $\$ 10$, comment $b$ at 60 (1942). It may be appropriate to incorporate this general qualification into rule 6 .

85. The fact that a party has notice of a void default judgment entered against him does not necessarily mean that he will have a reasonable opportunity to attack it. For example, a party may learn that a foreign judgment has been rendered against him despite lack of jurisdiction over his person. It may be unreasonable to expect him to institute an attack on the judgment in the foreign state by bringing a motion to vacate before the court entering the judgment. Moreover, if the plaintiff in the original action is outside the jurisdiction in which the original defendant resides, the latter will not be able to bring an independent action for equitable relief in the courts of his own state because of the lack of personal jurisdiction.

86. Where property is purchased at an execution sale under a void judgment, or from a party to a void judgment or decree determining rights in the property, a bona fide purchaser is not protected when that judgment or decree is set aside. See, e.g., Crump v. Knight, 256 Ala. 601,56 So. $2 d 625$ (1952) ; Townsend v. Tipton, 289 Ky. 766, 160 S.W.2d 161 (1942); Bladen County v. Breece, 214 N.C. 544,200 S.E. 13 (1938). Usually, however, if the judgment is not void on its face, the bona fide purchaser will be protected by the rule prohibiting extrinsic evidence when the judgment is collaterally attacked. But see Schott v. Linscott, 80 Kan. 536, 103 Pac. 997 (1909). Where the extrinsic evidence rule applicable to collateral attacks is not followed, see note 65 supra and accompanying text, the court may make an exception when third parties have relied on the record. Janove 
been rendered against a party who is not barred from contesting it under rule (6) or (7), he will have had no opportunity to make a timely attack. Accordingly, he will have been unable to take any steps to prevent the transfer of his property to a bona fide purchaser by virtue of the judgment. Under these circumstances, it would seem equitable to return the property to the original owner. Though the bona fide purchaser and the party voiding the judgment are equally blameless, the former has been apprised of the source of his title and should reasonably be held to assume the risk that a judgment valid on its face may be voided. In contrast, in situations where the judgment upon which the purchaser's title depends can be classified as voidable, the injured party will have had notice of the original proceeding and a chance to litigate the merits. Moreover, he may have been able to forestall a sale to a bona fide purchaser after the initial entry of judgment but prior to the final adjudication of his claims. ${ }^{87}$ When the party invalidating the judgment has been afforded these opportunities, he should not prevail over an innocent purchaser.

v. Bacon, 6 I11. 2d 245, 128 N.E.2d 706 (1955) ; Espadron v. Davis, 380 Ill. 199, 43 N.E.2d 962 (1942).

Where property is purchased at an execution sale under a voidable judgment, a bona fide purchaser retains title even though the judgment is later reversed or set aside. Gray v. Brignardello, 68 U.S. (1 Wall.) 627 (1863); Watt v. Cecil, 314 I1l. App. 274, 41 N.E.2d 346 (1942) ; Rose v. Cox, 297 Ky. 458, 179 S.W.2d 871 (1944) ; Dolan v. Hardman, $126 \mathrm{~W}$. Va. 480, 29 S.E.2d 8 (1944) (dictum). The judgment creditor is not protected when he is the purchaser. Russell v. Mohr-Weil Lumber Co., 114 Ga. 753, 40 S.E. 709 (1902) ; Pettis v. Johnston, 78 Okla. 277, 190 Pac. 681 (1920). Nor is a party who purchases directly from him. Flannery v. Kusha, 147 Minn. 156, 179 N.W. 902 (1920); Harjo v. Johnston, 187 Okla. 561, 104 P.2d 985 (1940).

The cases are in conflict as to whether the title of a purchaser from a party to a voidable judgment or decree determining rights in the property is protected. Lockwood v. Moore, 86 F.2d 689 (10th Cir. 1936) (protecting the title of the purchaser); Lake v. Tomes, 405 Ill. 295, 90 N.E.2d 774 (1950) (same). Contra, Vaughn v. Brue, 245 Ala. 107, 16 So. $2 d 17$ (1943); Goodson v. Lehmon, 225 N.C. 514, 35 S.E.2d 623 (1945).

For a complete treatment of this problem see Tainter, Restitution of Property Transferred Under Void or Later Reversed Judgments, 9 Mrss. L.J. 157 (1936).

87. In most jurisdictions the defendant may protect his property by filing a supersedeas bond pending appeal. See, e.g., FED. R. CIv. P. 73(d). See Ancateau v. Commercial Cas. Ins. Co., 318 I1l. App. 553, 48 N.E.2d 440 (1943) ; Rose v. Cox, supra note 86; Peck v. McLean, 36 Minn. 228, 30 N.W. 759 (1886); Glaze v. Johnson, 27 Tex. Civ. App. 116, 65 S.W. 662 (1901) (dictum). He may also be protected where he institutes some proceeding to avoid the judgment or decree determining rights in the property before third parties have purchased in reliance upon the record. Lake v. Tomes, stpra note 86; Smith v. Herdlicka, 323 Ill. 585, 154 N.E. 414 (1926). 